\title{
Evaluation of nootropic activity of Limonia acidissima against scopolamine- induced amnesia on rats
}

\author{
Kailas Mali ${ }^{1}$, Guruprasad Sutar ${ }^{2}$, Omkar Devade ${ }^{1}$, REMETH DIAS 3 \\ 1Department of Pharmacology, YSPM'S Yashoda Technical Campus, Faculty of Pharmacy, Wadhephata, \\ Satara 415011, Maharashtra, India.
} 2Department of Pharmacology, Annasaheb Dange College of B-Pharmacy, Ashta, Dist. Sangli, Maharashtra. 416301

${ }^{3}$ Department of Pharmacy, Government Polytechnic, National Highway No 6, Jalgaon 425002, Maharashtra, India

\section{Abstract}

Introduction: The present study was aimed to evaluate nootropic activity of Limonia acidissima on rats.

Materials and Methods: Methanolic extract of Limonia acidissima was used to evaluate nootropic activity, piracetam $(200 \mathrm{mg} / \mathrm{kg}$, i.p.) was used as standard and scopolamine $(1 \mathrm{mg} / \mathrm{kg}$, i.p.) was used to induce amnesia. Effect of drugs on learning and memory of rats was evaluated by using Y-maze task and elevated plus maze on scopolamine induced amnesia models. Locomotor activity was performed using actophotometer. Also, levels of acetylcholinestrease enzyme including histopathological study of rat brain were carried out.

Results: Methanolic extract of Limonia acidissima showed increase in the alternation of behaviour response and percentage spontaneous alteration with Y-maze task. While in elevated plus maze scopolamine induced amnesia model, methanolic extract of Limonia acidissima showed decreased in transfer latency, which is an indicative of cognition improvement. Methanolic extract increases locomotor activity in rats and decreases the levels of acetylcholinestrease enzyme significantly. The histopathological study with both low and high dose of extract showed effective regenerative score as compared to other group.

Conclusion: The results suggested that the administration of methanolic extract of Limonia acidissima enhances learning and memory in different experimental model. The histopathological study reveals nero-protective property of extract. The study indicates that the extract may be used in the treatment of Alzheimer disease.

Keywords: Nootropic activity, Limonia acidissima, Alzheimer disease, piracetam, scopolamine. 


\section{INTRODUCTION}

According to the world health organization, approximately 450 million people suffer from a mental or behavioral disorder ${ }^{[1]}$. Dementia is one of the age-related mental problems and a characteristic symptom of Alzheimer's disease $(\mathrm{AD})^{[2-4]} \mathrm{AD}$ is a progressive neurodegenerative and cerebrovascular disease ${ }^{[2,5]}$. It destroys cell in the brain causes problems with memory, un-usual behavior ${ }^{[6]}$, thinking, personality changes ${ }^{[7]}$ and finally ultimately death $^{[8-10]}$. AD characterized by the presence of excessive amounts of neurotic plaques containing amyloid $\beta$ protein loss of cholinergic markers in brain ${ }^{[7,11]}$. The central cholinergic system play important role in learning and memory process ${ }^{[12]}$. Acetylcholine (Ach) is one of the brain neurotransmitters involved in learning, memory and attention processes ${ }^{[13]}$. A decrease in acetyl choline in the brain of patients with $\mathrm{AD}$ appears to be a critical element in producing dementia $^{[7]}$. The centrally acting anti- muscarinic drugs like scopolamine impairs learning and memory in rodents and human being ${ }^{[4,13]}$. Age, stress and emotion are conditions that may lead to memory loss, amnesia, dementia, anxiety, schizophrenia and Alzheimer's diseases ${ }^{[14,15]}$.

There are few nootropic medicines which are used in treatment of $\mathrm{AD}$, called nootropic drugs belong to the class of psychotropic Agents ${ }^{[16]}$. The term nootropic was coined by Giurgea in 1972, from Greek noon (mind) and Greek tropos (turn) ${ }^{[17]}$. Nootropics are also referred as smart drugs, improve mental function such as memory, also increase blood circulation to brain and improves oxygen supply to brain ${ }^{[18]}$. Synthetic medicines like tacrine, dopnezil ${ }^{[19]}$, aniracetam, piracetam and rivastigmine are used for treatment of cognitive dysfunction and memory loss associated with $\mathrm{AD}^{[20]}$. But these drugs possess adverse effects including gastrointestinal disturbances and problems associated with their bioavailability ${ }^{[21]}$. To overcome these problems researchers are looking for herbal formulation which can overcome the adverse effect of synthetic drugs.

A number of herbs have been extensively studied and reported to have memory enhancing property ${ }^{[22]}$. The herbal plant Limonia acidissima is one of the important herbal drugs 
used in Ayurvedic systems of medicine ${ }^{[23]}$. It is also used against variety of conditions such as antimicrobial, hepatoprotective, antidiarrhoeal, anticancer, diuretic, hepatoprotective, antispermatogenic, antioxidant, anti diabetic and wound healing activities ${ }^{[24,25]}$.

The present study seeks to determine whether the methanolic extract of leaves and fruits pulp of Limonia acidissima shows nootropic activity in animal model.

\section{MATERIALS AND METHODS}

\section{Experimental Animals}

Wistar rats of either sex weighing between $(150-200 \mathrm{~g})$ body weights were used for the present study. They were housed under standard laboratory conditions (temperature $25 \pm 1{ }^{\circ} \mathrm{C}$ ), relative humidity $55 \pm 5 \%$ and $12.00: 12.00 \mathrm{~h}$ dark: light cycle) with standard pellet diet and water ad libitum.

The experiment was conducted as per the standard procedure prescribed by CPCSEA, India. The study protocol was approved by the IAEC of Yashoda Technical Campus, Satara (YSPM/YTC/PHARMA/20/2017).

\section{Drugs and chemicals}

Piracetam (Dr. Reddy's, India), Scopolamine hydrobromide (APP Pharmaceuticals, India) and normal saline were used for study. All other reagents and chemicals were of analytical grade and procured from Loba Chemie, Mumbai, India.

\section{Plant material and preparation of extracts}

The plant material was collected from Phaltan and was identified and authenticated by Department of Botany, Yashwantrao Chavan Institute of Science, Satara, Maharashtra, India. A voucher specimen (No-57) of plant material was kept in Department of Pharmacognosy, Yashoda Technical Campus, Satara. The fully ripe fruits and leaves of plant were kept for shade drying for one week. Then fruits were subjected to break open and rind, seed, pulp was separated and it was shade dried with leaves at room temperature more than two weeks, after drying rind, pulp and seeds were separately coarse powder and leaves was also separately coarse powder for further extraction. The coarsely powdered material was extracted with methanol by using Soxhlet extraction method for four days at $45^{\circ} \mathrm{C}$, at the ratio 1:1:1 (seeds, pulp and leaves). The obtained extract was filtered and concentrated (yield 8.8\%).

\section{Preliminary phytochemical investigation}


The methanolic extract was subjected for phytochemical test like alkaloids, flavonoids, glycosides, saponins, carbohydrate and tannins ${ }^{[26]}$.

Mayer's test, Wagner's test, Dragendroff's test and Hager's test was used to confirm presence of alkaloids. In brief, extract was treated with Mayer's reagent (potassium mercuric iodide). The formation of a yellow colored precipitate indicates the presence of alkaloids. The extract was treated with Wagner's reagent (iodine in potassium iodide). The formation of brown or reddish precipitate indicates the presence of alkaloids. Then extract was treated with Dragendroff's reagent (solution of potassium bismuth iodide). The formation of red precipitate indicates the presence of alkaloids. The extract was treated with Hager's reagent (saturated picric acid solution). The presence of alkaloids was confirmed by the formation of yellow colored precipitate.

Presence of flavonoids was confirmed by performing alkaline reagent test and lead acetate test. In alkaline reagent test, extract was treated with few drops of sodium hydroxide solution. Formation of intense yellow colour, which becomes colourless on addition of dilute acid, indicates the presence of flavonoids. In lead acetate test, extract was treated with few drops of lead acetate solution. Formation of yellow colour precipitate indicates the presence of flavonoids.

Molisch's test and Benedict's test was used to confirm presence of carbohydrate. Limonia acidissima extract was dissolved individually in $5 \mathrm{ml}$ distilled water and filtered. The filtrates were used to test for the presence of carbohydrates. In Molisch's test filtrate was treated with two drops of alcoholic $\alpha$-naphthol solution in a test tube. Formation of the violet ring at the junction indicates the presence of carbohydrates. In Benedict's test, filtrate was treated with Benedict's reagent and heated gently. Orange red precipitate indicates the presence of reducing sugars.

The presence of glycosides in extract was confirmed by modified Borntrager's test. The methanolic extract was hydrolyzed with dilute $\mathrm{HCl}$ and treated with ferric chloride solution. The resultant reaction mixture was immersed in boiling water for five minutes. The mixture was cooled and extracted with equal volumes of benzene. The benzene layer was separated and treated with ammonia solution. Formation of rose-pink colour in the ammonical layer indicates the presence of anthranol glycosides. 
Forth test and foam test was used to confirm presence of saponins. In Forth test, the extract was diluted with distilled water to $20 \mathrm{ml}$ and this was shaken in a graduated cylinder for 15 minutes. Formation of $1 \mathrm{~cm}$ layer of foam indicates the presence of saponins. In Foam test, the $500 \mathrm{mg}$ extract was shaken with $2 \mathrm{ml}$ of water. If foam produced persists for ten minutes it indicates the presence of saponins

Biuret's test, Million's test, Xanthoprotein test and Ninhydrin test was performed to detect proteins in extract. In Biuret's test, extract was treated with $4 \% \mathrm{w} / \mathrm{v}$ sodium hydroxide and $1 \% \mathrm{w} / \mathrm{v}$ copper sulphate. The change in colour of the solution to violet or pink indicates the presence of proteins. In Million's test, extract was treated with Million's reagent and heated. The appearance of white precipitate which changed to brick red on heating indicates the presence of proteins. In Xanthoprotein test, extract was treated with concentrated sulphuric acid. The appearance of white precipitate which turns to yellow on boiling and orange on addition of ammonium hydroxide indicates the presence of proteins containing tyrosine tryptophan. In Ninhydrin test, extract was treated with lead acetate solution and boiled on water bath for 10 min. The change in colour of solution to purple or blue indicates the presence of amino acids.

For presence of steroids, extract was treated acetic anhydride and sulphuric acid. The change in colour from violet to blue or green in sample indicates presence of steroid. Ferric chloride test was performed to detect phenols from extract. The extract was treated with 3-4 drops of ferric chloride solution. Formation of bluish black colour indicates the presence of phenols.

\section{Acute toxicity study}

The acute toxicity study was carried out according to OECD-423 guidelines. Six swiss albino female mice, weighing in the range of 20-25 gm, were administered the test solution at a dose of $2000 \mathrm{mg} / \mathrm{kg}$. The mice were critically observed for clinical signs, gross behavioral changes and mortality following the administration of the test formulation at different time intervals like $30 \mathrm{~min}, 1 \mathrm{~h}, 2 \mathrm{~h}, 4 \mathrm{~h}, 24 \mathrm{~h}, 48 \mathrm{~h}$ and $72 \mathrm{~h}$ up to a period of 14 days ${ }^{[27]}$.

\section{Behavioral study}

A rat was trained for behavioral study by conducting 1week training during which they did not received any plant extract or drug. The completely trained rat was selected for the study. An experiment was carried out in the light period between 8.00 am and 03:00 pm in a sound proof room. 


\section{Y maze task}

The five groups of animals were made, each group comprises 6 animals. Group I: Control group (normal saline), Group II: Negative group (Scopolamine $1 \mathrm{mg} / \mathrm{kg}$ i.p), Group III: Standard treatment (Piracetam $200 \mathrm{mg} / \mathrm{kg}$ i.p + Scopolamine $1 \mathrm{mg} / \mathrm{kg}$ i.p), Group IV: Low dose of extract + Scopolamine $(200 \mathrm{mg} / \mathrm{kg}$ p.o $+1 \mathrm{mg} / \mathrm{kg}$ i.p $)$, Group V: High dose of extract + Scopolamine $(400 \mathrm{mg} / \mathrm{kg}$ p.o $+1 \mathrm{mg} / \mathrm{kg}$ i.p).

$\mathrm{Y}$-maze task is a simple method to evaluate memory enhancing activity in laboratory animal, it is generally used to check behavioural pattern in animal. Wooden Y-maze was used for study. It consists of three arms with an angle of $120^{\circ}$ between each of the two arms. The each arm was $8 \mathrm{~cm}$ wide, $30 \mathrm{~cm}$ long and $15 \mathrm{~cm}$ deep. The arms were designated as start arm (A), novel arm with food stimuli $(\mathrm{B})$ and other arm $(\mathrm{C})^{[28]}$. In first trial, rat was placed just inside arm and allowed to move freely through apparatus for 5-10 min. In second trial, rat was placed in maze and explored the arm A, B and C systematically rat entered in each arm. The Ability to alternate requires that the rat know which arm they have already visited, total 13 entries were recorded of each rat visually and at last percentage of spontaneous alteration is calculated by using following formula $^{[29,30]}$ :

$$
\text { Percentage alteration }=\frac{\text { Number of positive entries }}{(\text { Total number of arm entries }-2)} \times 100
$$

\section{Scopolamine induced amnesia in Rats}

The grouping of animals was done as per Y maze task. All the animals were treated for 14 days and at the end of treatment period all the extract treated animals were subjected to scopolamine (1mg/kg i.p) 60 minutes after administration of extract, except the first group which served as vehicle contro

In this method, scopolamine is used as inducer which causes memory impairments in rats, which is calculated by using elevated plus maze (EPM) apparatus. EPM is made up of wooden material. It consists of two arms closed arm and open arm. In EPM task transfer latency was recorded. Rat was placed in arm and allowed to explore the maze for $1 \mathrm{~min}$, if rat is not transferred into other arm within $90 \mathrm{sec}$ gently pushed into other arm and transfer latency was considered as $90 \mathrm{sec}$. All groups of animals were treated for 14 days and at the end of treatment transfer latency is recorded served as parameter transfer latency on $14^{\text {th }}$ day (acquisition day) and $15^{\text {th }}$ day (retention day) ${ }^{[31]}$. 


\section{Locomotor activity}

Grouping of animals were done as per the Y maze task. Before test all rats were fasted for $4 \mathrm{~h}$ and treated with as per the grouping. One hour after treatment each rat was placed individually in actophotometer for a period of 10 minutes and locomoter activity was measured in terms of score. The difference in the Locomotor activity of all groups were recorded ${ }^{[6,32]}$.

\section{Estimation of acetylcholinestrease enzyme}

Animals were grouped as per the Y maze task. All rats were treated as per the groups with saline, scopolamine, piracetam and extract. After 60 minutes of treatment rats were decapitated, brains were removed quickly and stored in ice cold saline. Frontal cortex, hippocampus and septum were quickly dissected out on a petri dish chilled on crushed ice. The tissues were weighed and homogenized in $0.05 \mathrm{M}$ phosphate buffer $(\mathrm{pH} 7.2)$. The homogenate $(0.4 \mathrm{ml})$ was added test tube containing $2.6 \mathrm{ml}$ phosphate buffer and $100 \mu \mathrm{l}$ of 5,5-dithiobisnitrobenzoic acid (DTNB), and mixed. The absorbance of resulting mixture was measured at $412 \mathrm{~nm}$ using spectrophotometer. Stable value of absorbance was recorded. Then, acetylthiocholine iodide $(20 \mu \mathrm{l})$ was added and change in absorbance per minute was determined. The mean change in absorbance was considered for calculation using following formula and acetylcholinestrease activity is measured as $\mu \mathrm{M} / 1 / \mathrm{min} / \mathrm{gm}$ of tissue $^{[33]}$.

\section{$\mathrm{R}=(\delta$ OD volume of assay $/ \mathrm{E}) \times \mathrm{mg}$ of protein}

Where, $\mathrm{R}$ is the rate of enzyme activity in ' $\mathrm{n}$ ' mole of acetylcholine iodide hydrolyzed per minute per $\mathrm{mg}$ of protein, $\delta \mathrm{OD}$ is the change in absorbance per minute and $\mathrm{E}$ is the extinction coefficient $\left(1.36 \times 10^{4} \mathrm{M}^{-1} \mathrm{~cm}^{-1}\right)^{[34]}$.

\section{Brain histopathology}

After the treatment and behavioral studies, two animals from each group were sacrificed by excessive $\mathrm{CO}_{2}$ anesthesia and the brains were isolated and were kept in $10 \%$ formaldehyde solution. The brain was stained with crestyl violet, cerebellum and basal ganglia was studied under light microscope ${ }^{[35]}$.

\section{Statistical analysis}

The statistical analysis was carried out by using Graph pad prism software version 5.0 and results were compared by one-way ANOVA followed by Tukey's Multiple Comparison Test. A $p$ value less than 0.05 was considered as statistically significant. 


\section{RESULTS}

\section{Preliminary phytochemical investigation}

The results of the preliminary phytochemical screening of the methanolic extract of Limonia acidissima is given in table 1. The Limonia acidissima extract gave positive results for alkaloids, flavonoids, carbohydrates, glycosides, saponin, and absence of proteins, steroids, phenols.

Table 1: Phytochemical analysis of extract Limonia acidissima

\begin{tabular}{cll}
\hline Sr. No. & Phytochemical test & Result \\
\hline 1 & Test for Alkaloids & $+\mathrm{Ve}$ \\
2 & Test flavonoids & $+\mathrm{Ve}$ \\
3 & Test for carbohydrates & $+\mathrm{Ve}$ \\
4 & Test for Glycosides & $+\mathrm{Ve}$ \\
5 & Test for Saponin & $+\mathrm{Ve}$ \\
6 & Test for proteins & $-\mathrm{Ve}$ \\
7 & Test for steroids & $-\mathrm{Ve}$ \\
8 & Test for Phenols & $-\mathrm{Ve}$ \\
\hline +Ve indicates the presence of compounds, \\
-Ve indicates the absence of compounds.
\end{tabular}

\section{Acute toxicity test}

As female mice are more sensitive to drugs then male, in acute oral toxicity study female mice were taken as per OECD-423 guideline. Methanolic extract Limonia acidissima did not showed any toxic effects up to $2000 \mathrm{mg} / \mathrm{kg}$ oral dose. CNS stimulation parameters such as hyperactivity, irritability, tremors and convulsions were found to be negative in mice. CNS depressant parameters such as hypoactivity, narcosis and ataxia were found to be negative in mice.

\section{Y-maze task}

maze model proved to be a sensitive measure of spatial recognition memory. The effect on alteration behavior was studied on one parameter such as $\%$ alteration (Table 2). The negative control group showed significant $(p<0.001)$ decrease in the alternation of behavior when compared with the Normal control. The results of the standard treatment groups showed significant $(\mathrm{p}<0.001)$ increase in the alternation of behavior with respect to methanolic extract of Limonia acidissima $400 \mathrm{mg} / \mathrm{kg}$. 


\section{Scopolamine induced amnesia in rats}

Scopolamine induced amnesia in rat model was carried out by using elevated plus maze. The Scopolamine treated group showed a significant $(p<0.001)$ increase in transfer latency and memory retention on (acquisition $14^{\text {th }}$ ) and (retention $15^{\text {th }}$ ) day when compared with Normal control, standard treatment and a high dose of extract groups respectively. Whereas the Piracetam standard treatment group when compared methanolic extract of limonia acidissima at the dose of $200 \mathrm{mg} / \mathrm{kg}$ showed significantly $(p<0.01)$ i.e., decrease in transfer latency and memory retention on (acquisition $14^{\text {th }}$ ) and (retention $15^{\text {th }}$ ) day respectively. The result is given in Table 2.

Table 2: Effect of methanolic extract on alteration behavior and transfer latency in rats

\begin{tabular}{|c|c|c|c|c|}
\hline Group & Treatment & $\begin{array}{c}\text { Alterations } \\
(\%) \\
\end{array}$ & $\begin{array}{c}\text { Acquisition day } 14 \\
\text { (sec) }\end{array}$ & $\begin{array}{c}\text { Retention day } 15 \\
\text { (sec) }\end{array}$ \\
\hline $\mathrm{I}$ & $\begin{array}{l}\text { Normal Control: } \\
\text { (Normal saline, p.o.) }\end{array}$ & $66.31 \pm 2.45$ & $41.00=1.67$ & $38.33 \pm 1.22$ \\
\hline II & $\begin{array}{l}\text { Negative Control: } \\
\text { Scopolamine }(1 \mathrm{mg} / \mathrm{kg}, \text { p.o. })\end{array}$ & $35.80 \pm 3.19^{\mathrm{c} \#}$ & $14 \pm 3.37^{\mathrm{c \#}}$ & $71.50 \pm 3.50^{\mathrm{c \#}}$ \\
\hline III & $\begin{array}{l}\text { Standard treatment: } \\
\text { Piracetam }(200 \mathrm{mg} / \mathrm{kg}, \text { i.p. })+ \\
\text { Scopolamine }(1 \mathrm{mg} / \mathrm{kg}, \text { i.p. })\end{array}$ & & $25.67 \pm 1.22^{\mathrm{c \# c} \dagger}$ & $21.33 \pm 1.22^{\mathrm{c} \# \mathrm{c} \dagger}$ \\
\hline IV & $\begin{array}{l}\text { Low dose of extract } \\
(100 \mathrm{mg} / \mathrm{kg}, \text { p.o. })+ \\
\text { Scopolamine (1mg/kg i.p.) }\end{array}$ & $46.45 \pm 2$ & $34.83 \pm 1.24^{\mathrm{c} \dagger \mathrm{a} \dagger \dagger}$ & $31.50 \pm 1.35^{\mathrm{c} \dagger \mathrm{a}^{\dagger \dagger}}$ \\
\hline V & $\begin{array}{l}\text { High dose of extract } \\
(400 \mathrm{mg} / \mathrm{kg} \text {, p.o. })+ \\
\text { Scopolamine }(1 \mathrm{mg} / \mathrm{kg}, \text { i.p. })\end{array}$ & & $27.50 \pm 1.17^{\mathrm{c} \# \mathrm{c} \dagger}$ & $23.67 \pm 1.17^{\mathrm{c \# c} \dagger}$ \\
\hline
\end{tabular}

Values represent mean \pm SEM; $n=6$; Analysis was performed using one way ANOVA followed by Tukey's multiple comparison test; $p$ value less than 0.05 was considered as statistically significant. ${ }^{a} p<0.05,{ }^{b} p<0.01,{ }^{c} p<$ 0.001. "Data compared with Normal control. "Data compared with negative control. ${ }^{~}$ Data compared with standard treatment.

\section{Locomotors activity}

The locomotor activity in rats was carried out using actopotometer. The methanolic extract of Limonia acidissima showed nootropic activity by increasing locomotors activity (Table 3). The negative group showed decrease in locomotor activity as compared to normal control while extract treated groups showed significantly $(p<0.001)$ increased in locomotor activity as compared with negative treated group.

\section{Estimation of acetyl cholinesterase enzyme}

The result of levels of acetyl cholinesterase (AChE) is given in table 3. In normal control level of AChE was very low while in negative control it was found to be high. In case of 
piracetam treated group level of $\mathrm{AChE}$ was significantly reduced as compared to negative control group. The methanoloc extract of Limonia acidissima (200 and $400 \mathrm{mg} / \mathrm{kg}$ ) significantly ( $\mathrm{P}<0.001)$ lowered AChE activity as compared to negative control. The significant decrease in level of AChE indicated that Limonia acidissima is a potential anti-cholinesterase agent and possesses nootropic activity.

Table 3: Effect of methanolic extract of on locomotor activity and brain acetylch olinesterase levels in rats

\begin{tabular}{|c|c|c|c|}
\hline Group & Treatment & After treatment & $\begin{array}{c}\text { AChE } \\
(\mu \mathrm{M} / \mathbf{l} / \mathbf{m i n} / \mathbf{m g} \text { Protein })\end{array}$ \\
\hline $\mathrm{I}$ & $\begin{array}{l}\text { Normal Control: } \\
\text { (Normal saline, p.o.) }\end{array}$ & $562 \pm 30.12$ & $13.03 \pm 1.55$ \\
\hline II & $\begin{array}{l}\text { Negative Control: Scopolamine } \\
(1 \mathrm{mg} / \mathrm{kg} \text {, p.o.) }\end{array}$ & $42.61^{\mathrm{c \#}}$ & $24.09 \pm 1.56^{\mathrm{c \#}}$ \\
\hline III & $\begin{array}{l}\text { Standard treatment: } \\
\text { Piracetam }(200 \mathrm{mg} / \mathrm{kg}, \text { i.p. })+ \\
\text { Scopolamine }(1 \mathrm{mg} / \mathrm{kg}, \text { i.p. })\end{array}$ & & $15.52 \pm 1.13^{\mathrm{c} \dagger}$ \\
\hline IV & $\begin{array}{l}\text { Low dose of extract } \\
(100 \mathrm{mg} / \mathrm{kg}, \text { p.o. })+\text { Scopolamine }(1 \mathrm{mg} / \mathrm{kg} \text { i.p. })\end{array}$ & & $20.97 \pm 1.20^{\mathrm{c} \# \mathrm{c} \dagger \dagger}$ \\
\hline V & $\begin{array}{l}\text { High dose of extract } \\
(400 \mathrm{mg} / \mathrm{kg} \text {, p.o. })+\text { Scopolamine }(1 \mathrm{mg} / \mathrm{kg} \text {, i.p. })\end{array}$ & $48.18^{\mathrm{bHc} \dagger}$ & $18.00 \pm 1.19^{\mathrm{c \# c} \dagger}$ \\
\hline
\end{tabular}

Values represent mean \pm SEM; $\mathrm{n}=6$; Analysis was performed using one way ANOVA followed by Tukey's multiple comparison test; $p$ value less than 0.05 was considered as statistically significant. ${ }^{a} p<0.05,{ }^{b} p<0.01,{ }^{c} p<$ 0.001. "Data compared with Normal control. "Data compared with negative control. "Data compared with standard treatment.

\section{Histopathological analysis of scopolamine-induced amnesia in rats}

The results of histopathological analysis are given in figure 1 and table 4. Figure 1A shows the histopathological section of normal control rat showed neuronal degeneration without vascular degeneration and gliosis, while negative control group (Figure 1B) showed vascular degeneration, neuronal degeneration and gliosis. In case of standard treatment group (Figure 1C), low dose group (Figure 1D) and high dose group (Figure 1E), vascular degeneration, neuronal degeneration and gliosis was found to be less as compared to negative control group. The group II treated with scopolamine showed maximum pathological changes as compared to rest of the groups. Both low dose and high dose of methanolic extract of Limonia acidissima showed good regenerative score as compared to other group.

Table 4: Histopathology of the brain tissues in scopolamine induced amnesia in rat

\begin{tabular}{lccc}
\hline Group & $\begin{array}{c}\text { Vacuolar } \\
\text { degeneration }\end{array}$ & $\begin{array}{c}\text { Neuronal } \\
\text { degeneration }\end{array}$ & Gliosis \\
\hline
\end{tabular}




\begin{tabular}{|c|c|c|c|}
\hline Normal Control: (Normal saline, p.o.) & 0 & + & 0 \\
\hline Negative Control: Scopolamine (1 mg/kg, p.o.) & +++ & +++ & ++ \\
\hline $\begin{array}{l}\text { Standard treatment: Piracetam }(200 \mathrm{mg} / \mathrm{kg} \text {, i.p. })+ \\
\text { Scopolamine }(1 \mathrm{mg} / \mathrm{kg} \text {, i.p. })\end{array}$ & ++ & ++ & + \\
\hline $\begin{array}{l}\text { Low dose of extract }(100 \mathrm{mg} / \mathrm{kg} \text {, p.o. })+\text { Scopolamine } \\
(1 \mathrm{mg} / \mathrm{kg} \text { i.p. })\end{array}$ & ++ & ++ & + \\
\hline $\begin{array}{l}\text { High dose of extract }(400 \mathrm{mg} / \mathrm{kg} \text {, p.o. })+\text { Scopolamine }(1 \\
\mathrm{mg} / \mathrm{kg} \text {, i.p.) }\end{array}$ & + & ++ & \\
\hline
\end{tabular}

No abnormality detected (0); Damage/ active changes up to less than $25 \%(+)$; Damage/ active changes up to less than $50 \%(++)$; Damage/ active changes up to less $75 \%(+++)$; Damage/ active changes up to more than $75(++++)$

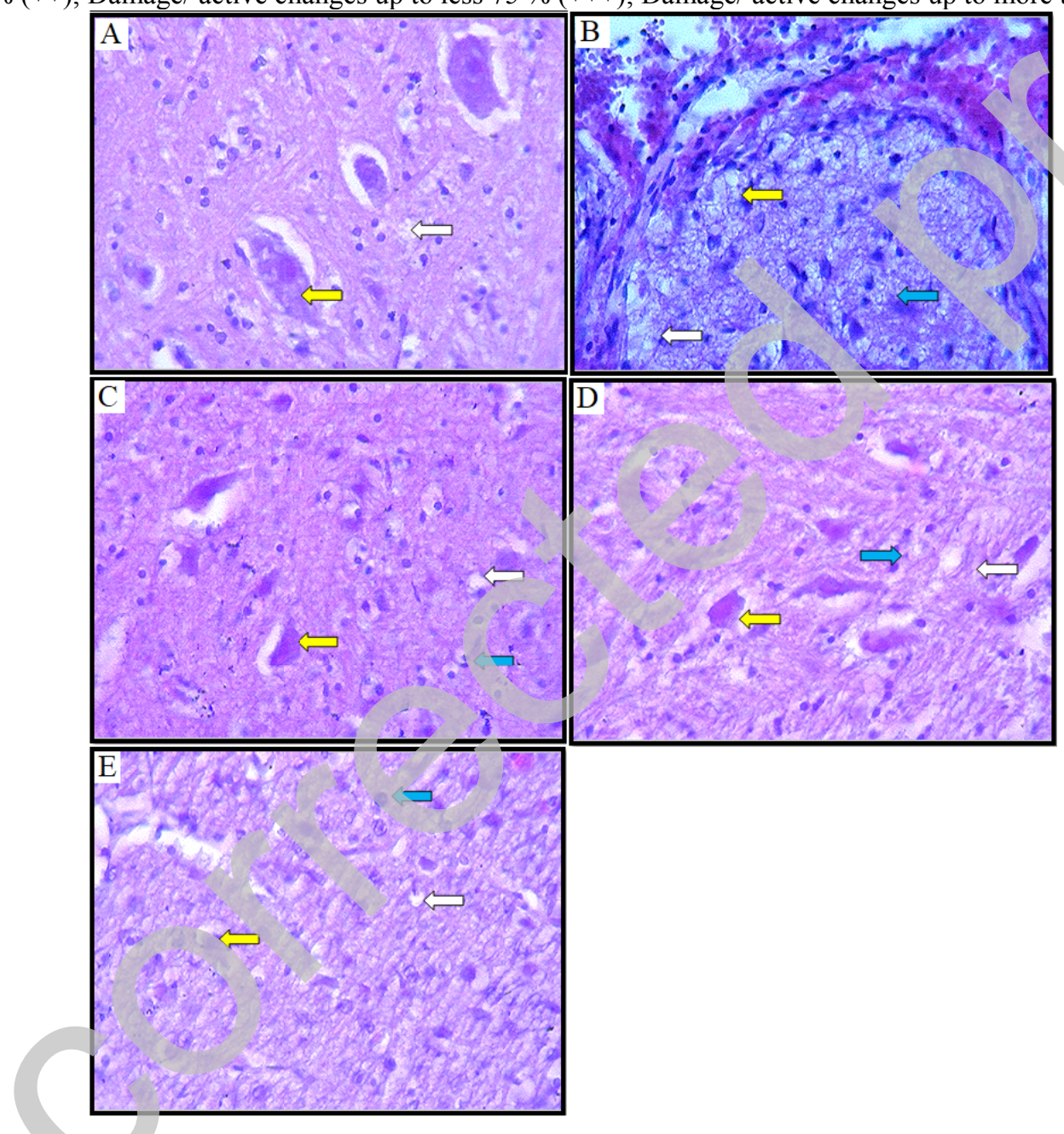

Figure 1: Histopathological observation of brain tissues in scopolamine-induced amnesia in rat.

A-Normal control: Section showing only stress amount of neuronal degeneration (yellow arrow)

B- Negative control: Section showing vascular degeneration (white arrow), neuronal degeneration (yellow arrow) and glial cell infiltration (blue arrow).

C-Standard treatment: Section showing vascular degeneration (white arrow), neuronal degeneration (yellow arrow) glial cell infiltration (blue arrow) less as compared with negative control. 
D-Low dose of extract: Section showing vascular degeneration (white arrow), neuronal degeneration (yellow arrow) glial cell infiltration (blue arrow) less as compared with negative control.

E-High dose of extract: Section showing vascular degeneration (white arrow), neuronal degeneration (yellow arrow) glial cell infiltration (blue arrow) less as compared with negative control.

\section{DISCUSSION}

Number of patients suffering from AD's are resign steadily day by day all over the world $^{[36]}, \mathrm{AD}$ is characterised by degenerative changes in the brain accompanied by loss of memory ${ }^{[37,38]}$. The main cause of $\mathrm{AD}$ is death of cholinergic neurons in basal forebrain area which results in the deficit of acetylcholine (Ach) ${ }^{[36]}$. Scopolamine is antimuscarnic agent, after administration it produces memory deficit ${ }^{[39]}$. Scopolamine induced memory loss was well reported animal model for screening anti-amnestic molecule ${ }^{[40]}$. It is a non-selective muscarinic receptor antagonist. It competitively inhibits muscarinic receptor for acetylcholine and reduces the level of acetylcholine and further, it causes impairment of learning acquisition short-term memory as it produces depression of cerebral cortex, especially of motar areas ${ }^{[41]}$.

Piracetam is a standard drug used to treat amnesia, dementia and other health problem like brain stroke, AD, vascular dementia, DLB and Huntington disease. Piracetam have ability to bind to receptor and increases Ach level in brain. It acts on cholinergic receptor and increases synthesis of Ach. It increases oxygen supply to brain. It has positive therapeutic effect which is useful in clotting, coaguiation and thrombosis disorder. It also acts as antioxidant/neurotonic. It also enhances number of acetylcholine receptor thus it might cause for enhancement of learning and memory ${ }^{[42]}$.

In this study, we have investigated the effect of methanolic extract of Limonia acidissima on spatial memory and neurodegeneration in animal model of Alzheimer's disease. The results clearly demonstrated that Limonia acidissima significantly improved spatial memory and neurodegeneration.

Methanolic extract of Limonia acidissima at doses $200 \mathrm{mg} / \mathrm{kg}$ and $400 \mathrm{mg} / \mathrm{kg}$ was administered orally for 7 days, which have improved learning and memory of rat significantly in the Y maze task. It was seen that when negative control group was compared with that of the 
standard treatment and extract group, both standard and extract treated groups showed significant $(\mathrm{p}<0.001)$ increase in percentage alteration behaviour.

In elevated plus maze model methanolic extract of Limonia acidissima possess nootropic activity by scopolamine-induced amnesia. The extract treated group showed significantly decrease in transfer latency and memory retention with $p<0.001$ when compared with negative and standard group at (acquisition $14^{\text {th }}$ ) and (retention $15^{\text {th }}$ ) day of the study, which is an indicative of cognition improvement.

Locomotor activity in patients suffering from $\mathrm{AD}$ is absent. Actophometer is model which is used to see the locomotor behaviors of animals. So, in present study actophometer model was used to know about the locomotor activity of animals treated with methanolic extracts. The methanolic extract of Limonia acidissima passes nootropic activity by increasing locomotor activity. The significant $(\mathrm{p}<0.001)$ locomotor activity was observed in rats treated with low dose and high dose treated groups.

Acetylcholine is considered as the most important neurotransmitter involved the regulation of cognitive functions. Cholinergic neurons plays important role in cognitive deficit associated with $\mathrm{AD}$ and neurodegenerative disease ${ }^{[31]}$. It has been demonstrated that impairment in learning, memory and behavior observed in the patients with dementia are caused at least by change within cholinergic system. In present study Limonia acidissima inhibited acetylcholinestrease enzyme, there by elevating acetylcholine concentration in the brain. The findings suggested that the possible neuroprotective role of Limonia acidissima. Thus, it seem that Limonia acidissima may prove to be useful in treatment of AD. However further investigations is warranted to explore the possible involvement of other neurotransmitters responsible for nootropic property of Limonia acidissima.

The histopathological study have also shown that both low dose and high dose of methanolic extract of Limonia acidissima were showed good regenerative score as compared to other group, which is good sign towards neuro-protective property to treat AD.

In few of the studies, the use of anti-inflammatory drugs showed reduction in symptoms f $A D{ }^{[43]}$. Epidemiological studies also confirmed suitability of non steroidal anti-inflammatory drugs to reduce incidence of $\mathrm{AD}^{[44]}$. Limonia acidissima have been reported to produce antiinflammatory action in rodents ${ }^{[45]}$. This anti-inflammatory property of Limonia acidissima might certainly helps to treat Alzheimer patients. 


\section{CONCLUSION}

In the conclusion, present study suggested that methanolic extract of Limonia acidissima provided significant protection in lowering AD. The methanolic extract of Limonia acidissima increased locomotor activity in rats and inhibited acetylcholinestrease enzyme, there by elevating acetylcholine concentration in the brain. The histopathology of brain had also showed good regenerative score, hence methanolic extract of Limonia acidissima can be used in the management of $\mathrm{AD}$. An extensive study on these lines is required in future to strength the methanolic extract of Limonia acidissima as novel and natural nootropic/memory enhancing agent.

\section{ACKNOWLEDGMENTS}

The authors are thankful to the Founder President, Prof. Dasharath Sagare, YSPM's Yashoda Technical Campus, Satara for providing the laboratory facilities. Authors are also thankful to Dr. D. S. Suryawanshi, Omega Laboratory, Lonand for providing facility of histopathology study.

\section{Source of Support: Nil}

Conflict of Interest: All authors approve the final manuscript and declare that there are no conflicts of interests.

\section{REFERENCES}

1. Gupta R, Singh HK. Nootropic potential of Alternanthera sessilis and Clerodendrum infortunatum leaves on mice. Asian Pacific J Trop Dis 2012;2(Suppl.1):S465-70.

2. Shivakumar L, Gouda ST, Rao NV, Richa V. Evaluation of Nootropic Activity of Polyherbal Formulation Sr-105. Int Res J Pharm 2011;2(4):101-7.

3. Ansari OA, Tripathi JS. Evidence based anti-dementing activity of Saraswata ghrita "a nootropic compound from Ayurveda. Int J Pharm Sci Res 2013;4(11):4194-202. Kumar KA, Kumar MS, Babu AN, Tony DE. Preclinical \& Pharmaceutical Research evaluation of nootropic activity of leaf extract of typha angustata. Int J Preclin Pharm Res 2014;5(2):57-60.

5. Parle M, Dhingra D, Kulkarni SK. Memory-strengthening activity of Glycyrrhiza glabra 
in exteroceptive and interoceptive behavioral models. J Med Food 2004;7(4):462-6.

6. Joshi H, Parle M. Nootropic activity of calyces of Hibiscus sabdariffa Linn. Iran J Pharmacol Ther 2006;5(1):15-20.

7. Kulkarni PD, Ghaisas MM, Chivate ND, Sankpal PS. Memory enhancing activity of cissampelos pariera in mice. Int J Pharm Pharm Sci 2011;3(2):206-11.

8. Kaur K, Kaur R, Kaur M. Recent Advances in Alzheimer â $€^{\mathrm{TM}}$ S Disease : Causes and Treatment. Int J Pharm Pharm Sci 2016;8(2):1-8.

9. Gupta A, Hemraj, Jalhan S, Jindal A, Upmanyu N. Various animal models to check learning and memory - A review. Int J Pharm Pharm Sci 2012;4(Supp1.3):91-5.

10. Naylor MD, Karlawish JH, Arnold SE, Khachaturian AS, Khachaturian ZS, Lee VMY, et al. Advancing Alzheimer's disease diagnosis, treatment, and care: Recommendations from the Ware Invitational Summit. Alzheimer's Dement 2012;8(5):445-52.

11. Kwon SH, Lee HK, Kim JA, Hong SI, Kim HC, Jo TH, et al. Neuroprotective effects of chlorogenic acid on scopolamine-induced amnesia via anti-acetylcholinesterase and antioxidative activities in mice. Eur J Pharmacol 2010;649(1-3):210-7.

12. Nabeshima T. Behavioral aspects of cholinergic transmission: role of basal forebrain cholinergic system in learning and memory. Prog Brain Res 1993;98:405-11.

13. Khakpai F, Nasehi M, Haeri-Rohani A, Eidi A, Zarrindast MR. Scopolamine induced memory impairment; possible involvement of NMDA receptor mechanisms of dorsal hippocampus and/or septum. Behay Brain Res 2012;231(1):1-10.

14. Une D, Ejaj MA, Tarde VA. Nootropic Activity of Saponins obtained from Tinospora Cordifolia Stem in Scopolamine induced Amnesia. Int J Pharma Res Rev 2014;3(2):2835.

15. Pal A, Jena M, Mishra S. Nootropic Activity of Zingiber Officinale in Albino Mice : A Behavioral and Neurochemical Approach. Res J Pharm , Biol Chem Sci 2013;4(4):1129_ 38.

16. Chintawar SD, Somani RS, Kasture VS, Kasture SB. Nootropic activity of Albizzia lebbeck in mice. J Ethnopharmacol 2002;81(3):299-305.

17. Gouliaev AH, Senning A. Piracetam and other structurally related nootropics. Brain Res Rev 1994;19(2):180-222.

18. Mali AA, Shenoy PA, Bhandawane DD, Nipate SS, Chaudhari PD. Screening of 
Nootropics: An overview of preclinical evaluation techniques. Int J Pharm 2012;2(1):159_ 80.

19. Gibbs RB, Mauk R, Nelson D, Johnson DA. Donepezil treatment restores the ability of estradiol to enhance cognitive performance in aged rats: Evidence for the cholinergic basis of the critical period hypothesis. Horm Behav 2009;56(1):73-83.

20. Winnicka K, Tomasiak M, Bielawska A. Piracetam - an old drug with novel properties Acta Pol Pharm - Drug Res 2005;62(5):405-9.

21. Mukherjee PK, Kumar V, Mal M, Houghton PJ. Acetylcholinesterase inhibitors from plants. Phytomedicine 2007;14(4):289-300.

22. Dwivedi P, Singh R, Malik MT jawaid T. A traditional approach to herbal nootropic agents: an overview. Int J Pharm Sci Res 2012;3(3):630-6.

23. Dhanapal R, Vijaya Ratna J, Sarathchandran I, Gupta M. Reversible antispermatogenic and antisteroidogenic activities of Feronia limonia fruit pulp in adult male rats. Asian Pac J Trop Biomed 2012;2(9):684-90.

24. Vijayvargia P, Vijayvergia R. A review on Limonia acidissima 1.: Multipotential medicinal plant. Int J Pharm Sci Rev Res 2014;28(1):191-5.

25. Priya Darsini DT, Maheshu V, Vishnupriya M, Nishaa S, Sasikumar JM. Antioxidant potential and amino acid analysis of underutilized tropical fruit Limonia acidissima L. Free Radicals Antioxidants 2013;3(2(S)):S62-9.

26. Kokate CK. Practical Pharmacognosy. 4th ed. New Delhi: Vallabh Prakashan; 1999.

27. OECD Guidelines for Testing Chemicals. Guideline 423 Acute Oral Toxicity. 2001. page $1-14$

28. Saxena V, Ahmad H, Gupta R. Memory enhancing effects of Ficus carica leaves in hexane extract on interoceptive behavioral models. Asian J Pharm Clin Res 2013;6(Suppl.3):109-13.

29. Kumar MN. Evaluation of Nootropic Activity in Mice. An Int Q J Biol life Sci 2016;1(2):45-54.

30. Sudeepthi NL, Eswar K, Pradesh A. Nootropic activity of acetone extract of curcuma amada using Y-maze and elevated plus maze. J Pharm Mol Biol 2013;1:51-66.

31. Sujith K, Darwin CR, Sathish, Suba V. Memory-enhancing activity of Anacyclus pyrethrum in albino Wistar rats. Asian Pacific J Trop Dis 2012;2(4):307-11. 
32. Vyawahare NS, Ambikar DB. Evaluation of neuropharmacological activity of hydroalcoholic extract of fruits of trapa bispinosa in laboratory animals. Int J Pharm Pharm Sci 2010;2(SUPPL. 2):32-5.

33. Varma RK, Singh L, Garg VK, Yadav P, Singh VK. Nootropic effect of Vigna Mungo (L.) hpper seeds extract in scopalamine induced amnesic rats. World J Pharm Pharm Sci 2016;5:1176-92.

34. Anantha Lakshmi J, Satyavati D. A study on nootropic activity of methanolic extract of Brassica oleraceae var. Caulorapa bulb in rodents. Asian J Pharm Clin Res 2015;3:107 15.

35. Hafez HS, Ghareeb DA, Saleh SR, Abady MM, El Demellawy MA, Hussien H, et al. Neuroprotective effect of ipriflavone against scopolamine-induced memory impairment in rats. Psychopharmacology (Berl) 2017;234(20):3037-53.

36. Chonpathompikunlert P, Wattanathorn J, Muchimapura S. Piperine, the main alkaloid of Thai black pepper, protects against neurodegeneration and cognitive impairment in animal model of cognitive deficit like condition of Alzheimer's disease. Food Chem Toxicol 2010;48(3):798-802.

37. Sheikh RA, Turaskar A, More S, Irene PR, Nathani MN. Study on nootropic activity of alcoholic extracts of flower of Securinega leucopyrus (AEFSL) in mice. Der Pharm Lett 2014;6(3):67-71.

38. Ahmed T, Gilani AH. Inhibitory effect of curcuminoids on acetylcholinesterase activity and attenuation of scopolamine-induced amnesia may explain medicinal use of turmeric in Alzheimer's disease. Pharmacol Biochem Behav 2009;91(4):554-9.

39. Higashida A, Ogawa N. Differences in the acquisition process and the effect of scopolamine on radial maze performance in three strains of rats. Pharmacol Biochem Behav 1987;27(3):483-9.

40. Hanumanthachar J, Navneet K, Jyotibala C. Evaluation of Nootropic Effect of Argyreia speciosa in Mice. J Heal Sci 2007;53(4):382-8.

41. Izquierdo I. Mechanism of action of scopolamine as an amnestic. Trends Pharmacol Sci 1989;10(5):175-7.

42. Khare P, Rituparna P, Pranit S, Noorpur K, Yadav G. Recent Advances on Piracetam. Adv Biol Res 2016;10(4):264-70. 
43. Rao SK, Andrade C, Reddy K, Madappa KN, Thyagarajan S, Chandra S. Memory Protective Effect of Indomethacin against Electroconvulsive Shock - Induced Retrograde Amnesia in Rats. Soc Biol Psychiatry 2002;3223(1):2000-3.

44. Breitner JCS. The role of anti-inflammatory drugs in the prevention and treatment of alzheimer's disease. Annu Rev Med 1996;47:401-11.

45. Khare S, Khare P, Jain SK. Anti-Inflammatory Activity of Ethanolic Extract of Feronia Limonia ( L .) Leaves. World J Pharm Pharm Sci 2014;3(5):870-6. 